\title{
Strategic management; concepts, benefits and process
}

\author{
Zeinab Khalili Sourkouhi ${ }^{1}$, Farshad Sameni Keivani ${ }^{2}$, \\ Mohammad Reza Almasi ${ }^{3}$, Morteza Bayat ${ }^{4}$, Sara Makouei ${ }^{5}$ \\ ${ }^{1}$ Department of Accounting, Roudsar and Amlash Branch, Islamic Azad University, Roudsar, Iran \\ ${ }^{2}$ The School of Social Sciences Universiti Sains Malaysia 11800 USM, Pulau Penang, Malaysia \\ ${ }^{3}$ Department of Accounting, Ataturk University, Turkey \\ ${ }^{4,5}$ Department of Accounting, Islamic Azad University, Zanjan Branch, Zanjan, Iran
}

\begin{abstract}
In order to improve the companies, it is important to know what is its present situation and types of barriers firms face when entering or exiting markets. So the firms need to plan and know strategic management. Nowadays, rapidly changing environment has caused strategic management has become one of the primary strategic topics in management of organizations. This paper explains the concepts of strategic, strategic management, Importance of strategic planning, how to do strategic management, its benefits and etc.
\end{abstract}

Keywords: Strategic management, management tools, strategy, planning

\section{Introduction}

Management in all firms' activities is the act of coordinating the efforts of people to accomplish desired aims using present resources efficiently. Management includes planning, organizing, staffing, leading or directing, and controlling an organization or effort for the purpose of achieving a aim. Resourcing includes changing the position of human resources, financial resources, natural resources and technological resources. Since organizations can be seen as systems, management can also be defined as human action, including design, to facilitate the production of beneficial results from a system. This perspective opens the opportunity to manage itself, a prerequisite to efforts to manage others. Due the limitation of resources, to achieve the goals of companies strategy is very important. Strategy is about to reach and keep a position of advantage over competitors by successive operation of known or emergent possibilities rather than committing to any specific fixed plan designed in the beginning. Strategy can be defined as follows:

Strategy is the direction and range of an organization over the long-period: which reaches benefits for the organization through its configuration of resources within a challenging environment, to meet market requirements of markets and to achieve beneficiary's expectations.

On the other hand, strategy is about:

- Direction of the firm's long-term (direction)

- What types of activities are involved in markets and which markets should a business compete in (Markets; scope)?

- How can the business carry out better than the competition in the markets (Advantage)?

- What facilities are needed in order to be able to compete (resources)?

What are the external environmental factors which affect the businesses' ability and power to compete (environment)?

- What are the expectations of those who have ability in and throughout the business (stakeholders)?

Strategic management analysis has normally taken place at the level of the company, and has removed the connector of company rival behavior.

Strategic management examines the main Projects taken by a firm's top management on behalf of owners, involving resources and function in indoor and outdoor environments. ${ }^{[1]}$ This requires identified of the Mission of the organization, perspective and goals, developing policies and applications, Often the condition of projects and plans, which are designed to reach these goals, and then allocating resources to perform the policies and plans, projects and plans. A balanced scorecard is often used to assessment the general performance of the business and its progress towards goals. Recent investigations and Progressive management theorists have supported that strategy needs to commence with stakeholders expectations and use a modified balanced scorecard which includes all stakeholders.

\section{What is strategic management?}

Strategic management is the science of formulating, implementing and assessment cross-functional decisions that will enable an organization to reach its goals. It includes the systematic identification of 
specifying the company's goals, nurturing policies and strategies to reach these goals, and obtaining and making available these resources to performance the policies and strategies to achieve the company's goals. So Strategic management merges integrates the activities of the various functional parts of a business, such as marketing, buying and selling, production etc, to achieve organizational objectives. Strategic management hopes to offer general direction to the firms have ties to the field of organization studies.

\section{Strategic Project Management Framework}

Strategic project management can be defined by connecting the different management processes of an organization. In general management processes include: strategic management, program management/technology management, department/ work unit management, project management, and knowledge management. Strategic management is the process by which the organization offers a unified management system and provides the organization to arrive its vision, mission, objectives, and aims. The stages of strategic management are as follows strategic planning, implementation planning, execution, and performance evaluation. Department or work unit management provides the everyday management of a work unit.

\section{Definition of Strategic planning}

Strategic planning is a process that is determined objectives and Policy of the activities and mission of the organization by using it at long run. Strategic planning helps managers in order to recognize the priorities and determine the main actions which it is necessary for the organizations to achieve their objectives.

\section{The Process of the Strategic Planning}

The process of the strategic planning includes some steps as follow:

1. To specify the future objectives of the organization: The determining of objectives includes recognition and proper diagnosis of the mission and goals of the organization.

2. To know of the available objectives and strategies of organization: The status of available strategy should be reviewed and due to the specific objectives be determined their differences features.

3. Analysis of environmental conditions: The purpose of the environmental analysis is to become aware of the economic, political, cultural and technical factors which affect on organizations and their objectives. Of course, in this step, the organizations should find the factors which are more effective on the organizations.

4. Analysis of the organizations resources: For this aim, it should provide a list of the important resources and it also should measure its impact on the organization's objectives. The organization's facilities should be evaluated subject to the key resources and strategic so the organization can find the overarching theme of the facilities to achieve their future goals.

5. Recognition of current situation: In this stage, due to the previous steps, the organization is achieved the detailed picture of the goals, resources and the available environmental conditions and then it analyze current situation after that it identify factors of imbalance between the resources objectives and the environmental conditions.

6. To determine the necessary changes in strategies: At this point, it is identified the gap between the objectives and the strategies of future and the current situation. So in order to reducing of this gap, it is necessary some changing in some items like the objectives, methods or resources and facilities.

7. To decide on the optimal strategy: In this stage, according to the evaluation criteria, it is identified the appropriate strategies and finally the best strategy is selected among them. It may be the past strategy which it needs to change or may be a new Strategy.

8. Implementation of the new strategy: After determining the proper strategy, it should be implemented, the first step it is performed as testing and after that step by step.

\section{The Strengths and Weaknesses, Opportunities and Threats Matrix (SWOT)}

The Matrix of Strengths, Weaknesses, Opportunities and Threats is one of the most important tools that managers can compare their information about organization and offer four strategies using it. These strategies include SO, WO, ST and WT strategies. The comparison of the internal and external major factors is one of the most difficult of providing of the matrix of threats and opportunities, strengths and weaknesses.

This model has the following features:

1- It mainly uses for the strategic business unit level.

2- It analysis the internal strengths and weaknesses and the environmental threats and opportunities.

3- It analysis the requirements, the values of the management and the social norms.

4- It follows the best state of adaptation between the firm and its environment by selecting the most appropriate strategy. 
In the SO strategy, the organization tries to take advantage of external opportunities. All of managers prefer to be in a position where their organization could use their organization's internal strengths to take advantage from the external events and trends. The organizations usually use WO, ST and WT strategies to achieve such a position of strategic means they can use the SO strategic. While an organization has a major weakness, it tries to remove the weakness or convert them into strengths. The aim of WO strategic is that the organization can use of the current opportunities in order to improve internal weaknesses. There are sometimes the suitable opportunities at outside of the organization but due to having internal weakness, the organization may not use this opportunity. To use of the WO strategic, the organization must get assistance through partnerships with other organizations in order to use of the opportunities or it should employ the qualified individuals in the field of the techniques and it tries to train others to use of these opportunities. In the ST strategy, the organization tries to reduce or remove the negative impacts resulting of the threat which are in the external environment by using its strengths. This does not mean that a strong organization inevitably will face many threats in the external environment.

\begin{tabular}{|c|c|c|}
\hline \multicolumn{3}{|c|}{ The points Matrix of the strengths and weaknesses, opportunities and threats (SWOT) } \\
\hline $\begin{array}{c}\text { Weaknesses } \\
\text { (List the weaknesses) }\end{array}$ & $\begin{array}{c}\text { Strengths } \\
\text { (List the strengths) }\end{array}$ & \\
\hline $\begin{array}{c}\text { WO Strategies } \\
\text { With the utilizing the } \\
\text { opportunities tries to remove } \\
\text { the weaknesses }\end{array}$ & $\begin{array}{c}\text { SO Strategies } \\
\text { With the utilizing the strengths tries } \\
\text { to take advantage from the } \\
\text { opportunities }\end{array}$ & $\begin{array}{c}\text { Opportunities } \\
\text { (List the opportunities) }\end{array}$ \\
\hline $\begin{array}{c}\text { WT Strategies } \\
\text { Reducing of the weaknesses } \\
\text { and to avoid the threats }\end{array}$ & $\begin{array}{c}\text { ST Strategies } \\
\text { To avoid threats use the strengths }\end{array}$ & $\begin{array}{l}\text { threats } \\
\text { (List the threats) }\end{array}$ \\
\hline
\end{tabular}

The organizations carry out WT strategic, they are defensive and their goal is reduce the internal weaknesses and avoid of the threats related to the external environment. An organization that has some internal weaknesses and faces many of threats in the external environment, it will be risky situation. In fact, such an organization shall struggle for their survival and tries to reduce of their activities in order to their survival (strategies reducing or transferring). It can be integrate in other organizations and finally declares bankruptcy or be liquidated.

This model can be used along with other models and the managers can design a suitable strategy for the organization by using it. In general, this model is more famous from other models and it uses widely by organizations.

\section{Conclusions}

The aim of this paper was to present an initial framework which combines the functions of strategic project management with possible tools to use in the process. This initial framework needs to be further defined and become operational. Following this further definition, specific tools can be researched. The impact of different tools on the management process and performance at each level can be understood. From this understanding, specific recommendations can be made to managers throughout the organization.

\section{References}

[1]. David, F.R. (2009). Strat.Mgmt.: Concepts and Cases. 12th ed. FT Prentice Hall, p. 36-37, 40, 48

[2]. Rothaermel, F. T. (2012). Strat.Mgmt.: Concepts and Cases. McGraw-Hill/Irwin, p. 5

[3]. Johnson, G, Scholes, K. Whittington, R. (2008). Exploring Corporate Strategy. 8th ed. FT Prentice Hall, p. 11-12

[4]. Cox, M. Z., Daspit, J., McLaughlin, E. and Jones III, R.J. (2012). Strat.Mgmt.: Is It an Academic Discipline? Journal of Business Strategies, Vol. 29 Issue 1, pp. 27-28 
[5]. Sameni Keivani. Farshad et al, 2013, “The Estimation Of The Potential Capacity Of Zakah -A Case Study Of Iran”, Journal of Basic and Applied Scientific Research, text road, ISSN 2090-4304

[6]. Sameni Keivani. Farshad et al, 2013, "The Creation Of bankruptcy prediction model with using Ohlson and Shirata models" Journal of Basic and Applied Scientific Research, text road, ISSN 2090-4304

[7]. Sameni Keivani. Farshad et al, 2013, "The Estimation of the Underdevelopment Degree of Different Regions- A Case Study of the Cities of Guilan Province in Iran" World Applied Sciences Journal, 22 (10): 1395-1400, 2013, ISSN 1818-4952

[8]. Sameni Keivani, Farshad., Mohmmadi, H., Khalili Sourkouhi, Z. and Sameni Keivani, Fariba, "Strategic Planning of Roudsar and Amlash University",2010-2012

[9]. Sameni Keivani. Farshad et al, "The Historical Lack of Capital Accumulation in Iran's Agricultural Part", 11(5) IOSR Journals of Business and Management (IOSR-JBM) e-ISSN: 2278-487X, p-ISSN: 2319-7668. Volume 10, Issue 4 (May. - Jun. 2013), PP 88-90

[10]. Sameni Keivani. Farshad et al, "Advantages and Barriers of E-Banking in Iran", Nature and Science Journal 2013;11(5)

[11]. Sameni Keivani. Farshad et al, "The role of Knowledge and confidence in reducing cost of electronic banking customers - a case study of Iran", The 5th International Conference on Financial Criminology (ICFC) 2013 "Global Trends in Financial Crimes in the New Economies",

[12]. Sameni Keivani. Farshad, "Synchronization of Economic Growth and Income Distribution." In 2011 International Conference on Sociality and Economics Development. IPEDR, vol. 10, pp. 7-11. 2011.

[13]. Sameni Keivani. Farshad et al, 2011, "Conceptual Approach to E-government, Targets and Barriers Facing its" at the International Conference on Construction and Project Management (ICCPM), September, 16-18, Singapore.

[14]. Sameni Keivani. Farshad et al, 2011, "Conceptual Evaluation E-commerce, Objectives and the Necessary Infrastructure" at the International Conference on Construction and Project Management (ICCPM), September, 16-18, Singapore

[15]. Kotnour, T.G., 2000, “Organizational Learning Practices in the Project Management Environment”,International Journal for Quality and Reliability Management, Vol. 17, No. 4/5, 393-406

[16]. Betz, F., 1998, Managing Technological Innovation - Competitive Advantage from Change, John Wiley \&Sons, Inc., New York

[17]. Price, R.M., 1996, "Executive Forum: Technology and Strategic Advantage", California Management Review, Vol.38, Iss.3, Spring 1996, 38-56

[18]. Andrews, K.R., 1998,” The Concept of Corporate Strategy” appears in The Strategy Process, intzberg, H., Quinn, J.B., Ghoshal, S. (eds.), Prentice Hall Europe, 51-60

[19]. Nair, S., K., 1997, "Identifying Technology Horizons For Strategic Investment Decisions"; IEEE Transactions on Engineering Management, New York; Aug 1997; Vol. 44, Iss.3, 227-236

[20]. Miyazaki, K., Kijima, K., 2000, "Complexity in Technology Management; Theoretical Analysis and Case Study of Automobile Sector in Japan", Technological Forecasting and Social Change, Volume 64, Issue 1, May 2000, 39-54

[21]. Thomas, C., 1994, "Learning from Imagining the Years Ahead", Planning Review, May/June 1994, 6- 10,44

[22]. Simpson, D., 1992, "Key Lessons for Adopting Scenario Planning in Diversified Companies", Planning Review, May/June 1992, 10 $17,47-48$ 